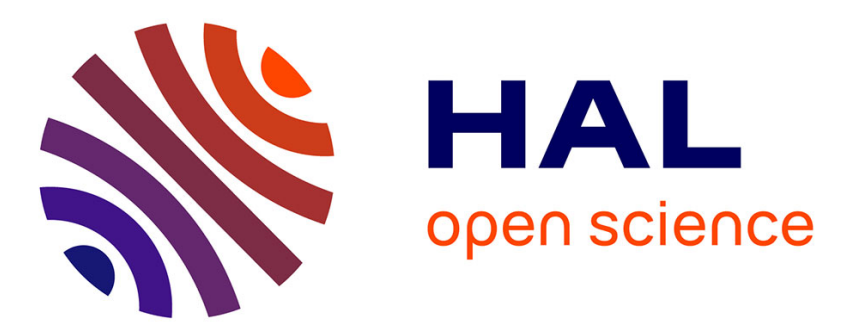

\title{
ESR dating applied to optically bleached quartz - A comparison with 40Ar/39Ar chronologies on Italian Middle Pleistocene sequences
}

Pierre Voinchet, A. Pereira, Sébastien Nomade, Christophe Falguères, Italo Biddittu, Marcello Piperno, Moncel Marie-Hélène, Jean-Jacques Bahain

\section{To cite this version:}

Pierre Voinchet, A. Pereira, Sébastien Nomade, Christophe Falguères, Italo Biddittu, et al.. ESR dating applied to optically bleached quartz - A comparison with 40Ar/39Ar chronologies on Italian Middle Pleistocene sequences. Quaternary International, 2020, 556, pp.113-123. 10.1016/j.quaint.2020.03.012 . hal-03012013v2

\section{HAL Id: hal-03012013 \\ https://hal.science/hal-03012013v2}

Submitted on 14 Dec 2020

HAL is a multi-disciplinary open access archive for the deposit and dissemination of scientific research documents, whether they are published or not. The documents may come from teaching and research institutions in France or abroad, or from public or private research centers.
L'archive ouverte pluridisciplinaire HAL, est destinée au dépôt et à la diffusion de documents scientifiques de niveau recherche, publiés ou non, émanant des établissements d'enseignement et de recherche français ou étrangers, des laboratoires publics ou privés. 


\title{
ESR dating applied to optically bleached quartz - a comparison with ${ }^{40} \mathrm{Ar} /{ }^{39} \mathrm{Ar}$ chronologies on Italian Middle Pleistocene sequences
}

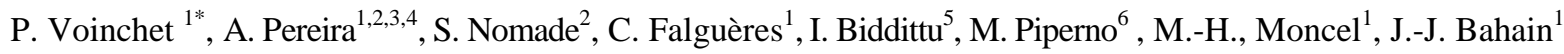 \\ ${ }^{1}$ UMR 7194 HNHP, Département Homme et Environnement, Muséum national d'Histoire naturelle, F-75013, Paris France \\ ${ }^{2}$ Laboratoire des Sciences du Climat et de l'Environnement, UMR 8212 LSCE/IPSL, CEA-CNRS-UVSQ \\ Université Paris-Saclay, F-91191 Gif-sur-Yvette, France \\ ${ }^{3}$ Ecole française de Rome, Piazza Farnese, IT-00186, Roma, Italy \\ ${ }^{4}$ Sezione di Scienze Preistoriche e Antropologiche, Dipartimento di Studi Umanistici \\ Università degli Studi di Ferrara, C.so Ercole d'Este I, 32, Ferrara, Italy \\ ${ }^{5}$ Italian Istitute of Human Paleontology, Piazza Ruggero Bonghi, 2, Anagni (FR), Italy \\ ${ }^{6}$ Universita di Roma "La Sapienza", Dipartimento Scienze Storiche, Archeologiche e Antropologiche dell'Antichita, sezione di Paletnologia, Piazzale \\ A. Moro, IT-00185 Roma (Italy) \\ * corresponding author - pvoinch@mnhn.fr
}

Abstract

The geological sequences of numerous Italian Lower and Middle Palaeolithic sites (central and southern Italy), found in fluvio-lacustrine contexts and rich both in archaeological and palaeontological remains, have recorded various volcanic events all along the Middle Pleistocene timescale. These sedimentary sequences made of detritic and volcanic materials are suitable to compare independent numerical geochronological methods and thus develop a multi-method approach relying especially ESR method applied to optically bleached fluvial quartz, and the ${ }^{40} \mathrm{Ar}{ }^{39} \mathrm{Ar}$ on single grain isotopic method applied to potassium feldspars. Several Middle Pleistocene Italian sites, including volcanic and fluvial but also archaeological levels, are used in this paper: Isoletta and Lademagne in Lazio and Notarchirico in Basilicata. In this contribution ESR measurements were performed using the $\mathrm{Al}$, Ti-Li and $\mathrm{Ti}-\mathrm{H}$ centres, in a multi-centre approach. We demonstrate in this study that ESR-based framework is overall consistent with the ${ }^{40} \mathrm{Ar} /{ }^{39} \mathrm{Ar}$ chronology that over the 700 and $350 \mathrm{ka}$ time window. This comparison obtained, using Al, Ti-Li and Ti-H centres, validates the multi centre approach proposed and demonstrates that the use of Ti-H for samples with De higher than 280-300 Gy provides systematically underestimated ages.

Keywords: ESR dating, optically bleached quartz, ${ }^{40} \mathrm{Ar} /{ }^{39} \mathrm{Ar}$ dating, Middle Pleistocene Italian sites

\section{Introduction}

Since the mid-1990s, Quaternary river deposits have been the subject of in-depth multidisciplinary studies, including systematic dating. This kind of research, partly initiated by a team of researchers from the Muséum National d'Histoire Naturelle (MNHN) in Paris, France, has led to the dating different stepped and embedded terrace systems for a large number of valleys in Europe and Asia by Electron Spin Resonance (ESR) method (see i.e. Laurent et al., 1994; Voinchet et al., 2004, 2010, 2013; Despriée et al., 2011). These numerous works have contributed to establishing a detailed chronostratigraphic framework of these river sequences covering most of the Pleistocene. Associated with several of these witnesses of the past history of rivers, several dozen Palaeolithic localities with lithic assemblages have also been dated using the same technique. The results obtained for each valley are consistent with each other, producing a robust geochronological framework, although there is often no independent age control available so far. Indeed, in these different valleys, the ESR dating method of quartz was often the only one that has been used, due to the nature or age of the studied sedimentary sequences. The absence of fossil faunal remains, linked to the extreme acidity of quartz sands, precludes any biochronological estimation for these localities as well as the use of the ESR/U-series method applied to teeth. In most cases, the fluvial sands, generally coarse and unconsolidated, are not suitable for magnetostratigraphic analysis (Pares et al. 2013). Finally, luminescence dating of sediments using standard procedures (OSL, IRSL, TL) has long limited the application of the method to Middle and Upper Pleistocene deposits (Arnold et al., 2003). As a result, alternative dating estimates by independent method has not been possible for the oldest deposits and sites of these 
valleys. This lack of control is considered by many as prejudicial and casts doubt on the relevance of the obtained chronology in particular regarding the exact period of arrival of the first human migration in Western Europe for example (Muttoni et al., 2013, Muttoni et al., 2018)

Fortunately, the particular case of central and southern Italian peninsula Middle Pleistocene river sequences, including K-rich volcanic material, allows the straightforward comparison of ESR dates with ages obtained using an independent reference method such as ${ }^{40} \mathrm{Ar} /{ }^{39} \mathrm{Ar}$. Indeed, the presence in Italy of numerous active volcanoes during the Middle Pleistocene, located mainly in the Tyrrhenian margin, has led to the emission of large and widespread tephra layers that are sometimes interspersed or mixed with fluvial deposits. These tephra are often dated by ${ }^{40} \mathrm{Ar} /{ }^{39} \mathrm{Ar}$ allowing the establishment of a robust and precise chronostratigraphic framework for this region (see example in Pereira et al., 2018).

Such confrontation of palaeodosimetric and radio-isotopic results allows to precise the chronology of the studied sequence and, if the data are in agreement, reinforce the strength of the obtained chronological framework. In the present contribution, we will compare ESR ages obtained on quartz using the multi-centre method (ESR-MC) with ${ }^{40} \mathrm{Ar}{ }^{39} \mathrm{Ar}$ dates on single feldspar grains with the following objectives (1) to verify/falsify the ESR results and (2) validate/invalidate the ESR - MC method. Of course, it is worth noticing that such comparison is only possible if stratigraphic knowledge of the sampling levels confirm the sub-contemporaneity of the studied geological layers and the evidenced volcanic events.

\section{ESR dating method}

Methodological developments in the ESR dating of optically bleached quartz grains over the two last decades have made it a reference method for the dating of Quaternary fluvial deposits. Among these developments, the most important is the use of the multiple centre (MC) approach (Toyoda et al; 2000, 2006; Tissoux et al., 2007; Duval and Guilarte, 2015).

Concerning the ESR dating of sedimentary quartz grains found in alluvial terrace deposits, it is essential that a "reset" of the geochronometers, here the paramagnetic centres (i.e. aluminium and titanium ones) occurred before the sediment deposition. Such reset is essential in order to date this event and not the formation of the quartz itself. This reset, also called optical bleaching in this case, depends of the UV sunlight exposure and occurs during river transport before the deposition of the sediment (Yokoyama et al., 1985; Voinchet et al., 2003; Voinchet et al., 2007). The main challenge for the ESR dating method lies in the estimation of the degree of bleaching of the analyzed quartz grains during the transport (i.e. complete resetting of the titanium centres or partial for aluminium ones). By chance, in quartz, the kinetics of bleaching varies considerably from one ESR centre to another. The ESR-MC method rests on the systematic measurement of both aluminum ( $\mathrm{Al}$ ) and titanium (Ti) centres in a given sample. The Al centre has long been the most used in quartz ESR dating (Voinchet et al., 2004) because aluminium is particularly abundant in this mineral and the corresponding ESR signal is easily measured and observed. In addition, this centre has a good thermal stability and therefore a longer lifetime. It can thus be used to date samples as old as several million years (Laurent et al., 1998). The Ti centres are less frequent and not always present in the studied samples. For dating, two Ti centres can be used, the Ti-Li and Ti-H centres. These two centres are much more lightsensitive than the $\mathrm{Al}$ ones and therefore totally reset during the transport. However, they are also much more radiosensitive than the $\mathrm{Al}$ centre and saturate much faster. Despite these caracteristics that made the Ti centres more difficult to use, they can lead to more precise results for "recent" samples, between a few tens of thousands years (Ti-H) to a few hundred thousand years (Ti-Li). Although the behavior of the Ti-H centre with respect to gamma irradiation allows it to be used for geochronological purposes, it remains a centre that saturates faster than Ti-Li one. It can therefore only be used for low palaeodose and/or recent samples (Miallier et al., 1994).

The rational of the MC approach is based on the differences observed between the $\mathrm{D}_{\mathrm{e}}$ determined from these different centres for a given sample. As these differences are directly related to the quality of the initial light bleaching of the sample it is currently considered as the best way to assess the uncertainty associated with an eventual incomplete bleaching of the Al or Ti-Li ESR signals prior to the sediment deposition.

\section{Sampling}


Three Italian archaeological sites were sampled in the frame of this work: Isoletta and Lademagne sites in Lazio and Notarchirico in Basilicata (Fig.1).

All of the analyzed geological levels are fluvial layers, containing fine quartz grains and characterized by the occurrence of volcanic minerals, allowing them to be dated using the ${ }^{40} \mathrm{Ar} /{ }^{39} \mathrm{Ar}$ single cristal approach. The ${ }^{40} \mathrm{Ar} /{ }^{39} \mathrm{Ar}$ isotopic technique is one of the most accurate and precise dating methods available for Middle Pleistocene time range (Pereira et al., 2015; 2018). The major characteristic of the ${ }^{40} \mathrm{Ar} /{ }^{39} \mathrm{Ar}$ dating technique, which gave us the possibility to use this approach, is the possibility to date single crystal. In fact, the individual dating of volcanic crystals allow the identification of the corpus of volcanic events reworked and drained in sedimentary layers. In a geological layer, the juvenile crystals population highlighted by the related probability diagram gives chronological information on the age of youngest volcanic event reworked (see Pereira et al., 2015, 2018 for further explanations). The uncertainties obtained on the calculated ages are ranging between 1 to $5 \%$.

The volcanic materials found at Isoletta and Lademagne sites are originated from the nearby volcanic complexes of Colli Albani or Ernici mounts (Pereira et al., 2018) whereas at Notarchirico they derived from the mount Vulture stratovolcano activity (Lefèvre et al., 2010; Pereira et al., 2015).

\subsection{Isoletta site}

Isoletta is located in the Ceprano tectonic basin (Fig. 1) at the confluence of the Liri and Sacco Rivers, near the town of Pofi in the Frosinone Basin, few kilometers south-east of the Campogrande/Ceprano Homo heidelbergensis site location (Fig. 1). It displays a typical alluvial terrace stratigraphic sequence, particularly thick (more than $30 \mathrm{~m}$ ) (Fig.2. and 4). This sequence was exposed thanks to the high-speed train railways construction and was sampled in 2000. Three main units were then individualized: gravels at the base, surmounted by very fine sediments (silts and clays) rich in organic matter and finally an alternation of medium to coarse sand beds over more than $10 \mathrm{~m}$ (Fig.2). On this site, two archaeological levels were identified (Fig.2): the first one in bottom gravels, characterized by Mode 1 lithic (cores-and-flakes type) and bones industries and the second, in a sandy layer of the upper unit, displayed Mode 2 (Acheulean) technology and "Galerian" fauna (first half of the Middle Pleistocene) (Biddittu, 1974, Sardella et al., 2006).

The gravel level at the bottom and the sand levels of upper sequence are very rich in reworked volcanic material (Fig.2.). Four samples for ESR dating were taken from different levels: the first in the coarse level of the base (ESR 1) and the three others (ESR 2, 3 and 4) in three (decimetric) beds of medium to fine sand showing fluvial sedimentation features. ESR 3 sample corresponds to the higher archaeological level ("Acheulian level", see GA6Z, Pereira et al., 2018). The basal part of the sequence as well as the levels having provided ESR2 and ESR4 contain volcanic minerals (potassium feldspars) dated by ${ }^{40} \mathrm{Ar} /{ }^{39} \mathrm{Ar}$.

\subsection{Lademagne site}

Lademagne site, located $5 \mathrm{~km}$ from Isoletta in the Ceprano tectonic basin (Fig. 1), was discovered in 1965. The stratigraphic sequence is mainly composed of sandy-gravelly deposits inter-bedded with volcanic rich sediments (Fig.3), and is very similar to the upper part of Isoletta's sequence. Two archaeological layers with both Mode 2 industries are mentioned in the literature (Biddittu et al., 2012) and present palaeontological and archaeological assemblages close to those of Isoletta (Biddittu et al., 2012). One sample was taken for ESR dating at the top of the stratigraphy (named Lad Sup) and can be compared with one sample taken in the same level for ${ }^{40} \mathrm{Ar} /{ }^{39} \mathrm{Ar}$ dating on single crystal (named also Lad Sup in Pereira et al, 2018).

\subsection{Notarchirico}

Discovered in 1979, Notarchirico site (Piperno et al., 1999) is an Early Middle Pleistocene site of the Venosa basin (Fig.1.). The sequence is seven meters thick and is mainly composed of volcanoclastic 
sediments deposited and reworked in a fluvial environment. Many stratigraphical levels are rich both in volcanic materials coming from the close Monte Vulture stratovolcano and quartz transported by the river (Fig.4. and 5).

This site is characterized by repeated periods of human occupation, most part of them linked to butchery activities. A total of eleven archaeological layers (Fig. 5. Piperno et al., 1990, 1999) are published (Piperno and Tagliacozzo, 2001). One femur attributed chronologically to Homo heidelbergensis has been discovered in the upper part of the sequence and some of the archaeological levels contain bifaces referred to Mode 2 technology (levels A, $A_{1}, B, D$ and F, Piperno and Tagliacozzo, 2001).

Three levels have been sampled at Notarchirico, one in the medium part of the sequence (level 2-6, Notarchirico 2-6 sample) and two in the newly investigated bottom part (level H1 and H1c, Notarchirico H1 sample and Notarchirico H1c sample) (Fig.4. and 5). For now only level 2-6 has been dated by ESR (Al) and ${ }^{40} \mathrm{Ar} /{ }^{39} \mathrm{Ar}$ methods (Pereira et al., 2018).

\section{Material and method}

4.1 ESR dating

Sediment samples were prepared according to the procedure used in the Muséum National d'Histoire Naturelle (MNHN) laboratory (Voinchet et al, 2004). Firstly, the 100-200 $\mu \mathrm{m}$ grain size fraction, the most easily bleached during river transport (Voinchet et al. 2015), was collected by wet sieving. The organic matter was removed by an attack with hydrogen peroxide $(30 \%)$ and the carbonates were destroyed using hydrochloric acid (36\%). After ultrasonic use, in order to break the weaken minerals with cleavage plane, the samples were then attacked with HF (40\%) during $1 \mathrm{~h} 40 \mathrm{~min}$ to firstly destroy the feldspar grains and then to remove the external part of the quartz grains (etching of about $10 \mu \mathrm{m}$ ) (recent works have demonstrated that the previously recommended 40min-long attack was sometimes not enough to remove all the feldspar grains, especially in case of very feldspar rich sediment (Tissoux et al, 2017). A new $\mathrm{HCl}$ attack eliminates then the fluorides formed during this etching. The heavy minerals and the magnetic minerals are then removed with a sodium polytungstate heavy liquor at $\mathrm{d}=2.72 \mathrm{~g} / \mathrm{ml}$ and with magnets respectively.

The quartz grains thus separated were dated using the Multiple Aliquots Additive Dose (MAAD) method. Each sample was divided into 11 aliquots (each one, around $100 \mathrm{mg}$, composed by several thousand grains). Nine of them were irradiated using a ${ }^{60} \mathrm{Co}$ source (CEA, Saclay) with a dose rate of $260 \pm 20 \mathrm{~Gy} / \mathrm{h}$. The following doses were applied to these aliquots: 264, 431, 653, 1048, 1663, 2640, $4460,8010,12500 \mathrm{~Gy}$. In order to evaluate the residual non-bleachable ESR signals from the Aluminium centre, one aliquot was exposed to a SOL2 sunlight simulator (Dr Hönle) for about 1600h. The last aliquot was not more treated (natural aliquot).

All aliquots were then measured by ESR. These measurements were made at the MNHN dating laboratory (Paris, France), with an EMX Bruker X-band spectrometer with a high sensitivity spherical cavity. These measurements were made at low temperature $(\sim 100 \mathrm{~K})$ by cooling the cavity with liquid nitrogen.

To apply the multi-centre method as defined by Toyoda et al (2000), the ESR signal intensities of the $\mathrm{Al}$ and $\mathrm{Ti}$ centres (Ti-Li and $\mathrm{Ti}-\mathrm{H})$ were measured. These different centres were measured on a single spectrum (fig.6) using the following acquisition parameters: a $5 \mathrm{~mW}$ microwave power, 1024 points resolution, $20 \mathrm{mT}$ sweep width, $100 \mathrm{kHz}$ modulation frequency, $0.1 \mathrm{mT}$ modulation amplitude, $40 \mathrm{~ms}$ conversion time, $20 \mathrm{~ms}$ time constant.. Two cumulative scans were performed to limit background noise on the Ti centres. The signal intensity of $\mathrm{Al}$ centre was measured between the top of the first peak at $\mathrm{g}=2.018$ and the bottom of the 16th peak at $\mathrm{g}=2.002$ (fig.6) of the Aluminum hyperfine structure (Toyoda and Falguères, 2003). The ESR intensity of the Ti-Li centre was determined by measuring the difference between the peak top $(\mathrm{g}=1.913)$ and the baseline (Toyoda et al 2006, Tissoux et al 2007, Duval et al, 2015), while the intensity of the Ti-H centre was measured between the peak apex ( $\mathrm{g}=1.917)$ and the baseline (fig.6) (Toyoda et al, 2006, Tissoux et al, 2007, Duval et al, 2015).

Due to the angular dependence of the signal, linked to the heterogeneity of the sample grains, each aliquot of a given sample was measured 3 times after a tube rotation of about $120^{\circ}$ of its initial position in the cavity. In addition, the measurements were repeated three times on different days to test the repeatability of the measured intensities and as a result of the equivalent Dose obtained. As a 
result, nine intensities were obtained for each measured signal (Ti-Li, $\mathrm{Ti}-\mathrm{H}$ and $\mathrm{Al}$ ) in each aliquot of all quartz samples studied. ESR intensities are calculated using the average of the nine measurements. For aluminium signals, the value of the ESR intensity of the bleached aliquot was systematically subtracted from the ESR intensities of the other aliquots to account the centres that cannot be bleached by light (DAT, Tissoux et al., 2012). The bleaching rate $\delta_{\mathrm{bl}}(\%)$ is then determined by comparison of the ESR intensities of the natural and bleached aliquotes $\left(\delta_{b l}=\left(\left(\mathrm{I}_{n a t}-\mathrm{I}_{\mathrm{bl}}\right) / \mathrm{I}_{\mathrm{nat}}\right) \times 100\right)$. In theory, a difference in result between these $\mathrm{Al}$ and $\mathrm{Ti}$ centres will indicate poor bleaching condition during transport. In this case, $\mathrm{Al}$ ages will be considered as maximum ages and $\mathrm{Ti}-\mathrm{H}$ as minimum ones, $\mathrm{Ti}-\mathrm{Li}$ ages will be considered to be the closest to the quartz deposition age.

After normalization of ESR intensities by aliquot mass and receiver gain, the equivalent doses $\left(D_{E}\right)$ were then determined from the averaged ESR intensities versus the dose growth curves using a coupled exponential and linear function for Al, Ti-Li and Ti-H centres (Duval et al, 2009, Duval, 2012; Voinchet et al., 2013). For Ti-H center, due to the shape of growth curve (fig.7), we tested two functions (fig 7.), Ti-2 (Duval et al.) by taking into account all the points and expo+lin by taking into account only the points of the curve in its increasing part. The results are extremely close and we have chosen to use only the expo+lin results, which describe more the physical phenomenon of filling ESR centres (Woda and Wagner, 2007).

All these determination was obtained using with Microcal OriginPro 8 software with 1/12 weighting The dose rate $\left(\mathrm{D}_{\mathrm{a}}\right)$ determined from the radionuclides contents of the sediment surrounding the sample was obtained to sum the alpha, beta, gamma and cosmic-ray contributions. Gamma dose rate was determined by in situ measurements directly at the sampling point using an Inspector 1000 gamma spectrometer $\left(\right.$ Canberra $\left.^{\circ}\right)$, except for the Isoletta section, sampled in 2000 before the systematic use of gamma spectrometer on field by our team and now not yet accessible. These gamma doses were estimated using the threshold approach (Mercier and Falguères 2007). External alpha and beta contributions were calculated from the sediment radioelement contents ( $\mathrm{U}$, Th and $\mathrm{K}$ ) as determined in the laboratory by high resolution and low background gamma-spectrometry. The internal dose rate was considered as negligible because of the low contents of radionuclides usually found in quartz grains (Murray and Roberts 1997; Vandenbergue et al. 2008).Age calculations were performed using the dose-rate conversions factors from Guerin et al (2011) and a k-value of $0.15 \pm 0.1$ (Yokoyama et al., 1985). Alpha and beta attenuations estimated for the selected grain sizes from the tables of Brennan et al., (1991) and Brennan (2003) respectively. Water contents (W\%) were estimated by the difference in mass between the natural sample and the same sample dried for a week in an oven at $50^{\circ} \mathrm{C}$ and water attenuation were then determined using formula from Grün (1994). The cosmic dose rates were calculated from the equations of Prescott and Hutton (1994). ESR age estimates are given with one sigma error range. The "doses rate" and ages were calculated using a specific excel template including data mentioned previously.

When it is possible, weighted average ages combining the different ESR centres, are calculated for using IsoPlot 3.0 (Ludwig, 2003). Mean Square of Weighted Deviates (MSWD) and Probability (P) are then given for each result.

\section{$4.2{ }^{40} \mathrm{Ar} /{ }^{39} \mathrm{Ar}$ analyses}

The single crystal dating using ${ }^{40} \mathrm{Ar} /{ }^{39} \mathrm{Ar}$ isotopic method is actually one of the most accurate methods available for Middle Pleistocene time range (Pereira et al., 2015; 2018) and gave us the possibility to date and identify the volcanic events recorded in sedimentary layers.

The ${ }^{40} \mathrm{Ar}{ }^{39} \mathrm{Ar}$ method is the most efficient and precise for Middle Palaeolithic using K-rich volcanic minerals which could have up to 11 to $18 \%$ of $\mathrm{K}$ such as sanidines or feldspathoïds leucites. We therefore use mainly these minerals to establish an ${ }^{40} \mathrm{Ar} /{ }^{39} \mathrm{Ar}$ chronology (see Pereira et al., 2015, 2018). The analytical protocols followed and the details about the ${ }^{40} \mathrm{Ar} /{ }^{39} \mathrm{Ar}$ ages mentioned in this study are all presented in Pereira et al., 2015, 2018 and Moncel et al., 2018. All ${ }^{40} \mathrm{Ar} /{ }^{39} \mathrm{Ar}$ ages discussed hereafter are calculated using the potassium total decay constant Steiger and Jäger, 1977 and the monitor standard ACs-2 dated at $1.193 \mathrm{Ma}$. We are fully aware than other calibrations exist such as the total decay constant of Renne et al., 2011 and the ACs-2 at 1.1891 Ma (e.g. Niespolo et al., 2017) but for the purpose of this article, considering that the implied age difference of $\leq 1 \%$ is 
negligible compared to the uncertainties of the ESR method. We therefore in the scope of this contribution do not discuss the various parameters than can be used to calculate ${ }^{40} \mathrm{Ar} /{ }^{39} \mathrm{Ar}$ ages.

\section{Results and discussion}

$\mathrm{U}$, Th and $\mathrm{K}$ activities of the different sediment samples are shown in table 1 . Are shown in table 2 alpha and beta doses derived from the radioelements content given in table 1, as well as in situ gamma measurement data, cosmic doses, water contents (W\%), bleaching rates $(\mathrm{Bl} \%)$, and equivalent doses with indication of the quality of the ESR growth curve fitting $\left(\mathrm{r}^{2}\right)$.

In all the analyzed samples, the aluminium centre could be used. The Ti-Li centre was used for almost all samples except Notarchirico 2-6. For this sample, Ti signal is to weak to be possible to distinguish it between background noise, even with two scan. It is worth noticing that if titanium is quite absent from Notarchirico 2-6 quartz sample, the ones extracted from levels Notarchirico H1 and Notarchirico H1c allow the use of multi-centre approach.

The Ti-H centre, has only been used for samples from Isoletta and Notarchirico $\mathrm{H} 1$ and $\mathrm{H} 1 \mathrm{c}$ levels. The Ti-H signal shows frequently a generally signal-to-noise lower than $\mathrm{Al}$ or Ti-Li signals, and is sometimes impossible to measure on the ESR spectra. It is the case for the Lademagne sample where $\mathrm{Ti}-\mathrm{H}$ it is inseparable from the background noise. The comparison between the De obtained using Expo+Lin and Ti-2 function give a minimal difference (table 2) and does not change our interpretation.

Concerning the dose rate determination, no in situ gamma measurements could be made for samples taken at the Isoletta site in 2000. In this case, the gamma value was determined in the laboratory from a representative sample of the raw sediment.

\section{$\underline{5.1 \text { Isoletta }}$}

For Isoletta samples the results obtained by ESR applied on quartz using Titanium-Lithium and Aluminium centres are consistent within $1 \sigma$, with the available ${ }^{40} \mathrm{Ar} /{ }^{39} \mathrm{Ar}$ ages, except of sample ESR 1 for which the three centres give very different and clearly overestimated results. (Tab. 3). For ESR2 and ESR3 samples, the use of Ti-H center provide provides strongly younger ages, while, the ESR4 equivalent doses obtained using $\mathrm{Al}$ and $\mathrm{Ti}-\mathrm{Li}$ centres are small (lower than $300 \mathrm{~Gy}$ ) and similar to the value derived from Ti-H . In this particular case, Ti-H does not lead to underestimate the ESR age and the three ages could be used for the average age calculation for this sample.The relatively large error ranges observed for these ESR ages are explained by relatively poor quality growth curves (intensity vs. ESR dose of irradiation) with $\mathrm{r}^{2}$ sometimes lower than 0.99 (Tab 2). For Isoletta ESR 2 and ESR 3 ESR 4 samples, the close $\mathrm{D}_{\mathrm{e}}$ obtained using the $\mathrm{Al}$ and Ti-Li centres allows us to give a weighted average age for each level, calculated from the both results. For Isoletta ESR 4 samples, the close $D_{e}$ obtained using the $\mathrm{Al}, \mathrm{Ti}-\mathrm{Li}$ and $\mathrm{Ti}-\mathrm{H}$ centres permits us to give a weighted average age calculated from the three centres results. Then, weighted average ages are calculated using IsoPlot 3.0 (Ludwig, 2003 ) and given at $95 \%$ of confidence. For Isoletta ESR2 sands, weighted mean ages is $442 \pm 58 \mathrm{ka}$ $(2 \sigma$, Full external error, MSWD $=0.65$ and $\mathrm{P}=0.42)$. Mean ages of $349 \pm 90 \mathrm{ka}(2 \sigma$, full external uncertainty, MSWD $=0.080$ and $\mathrm{P}=0.78)$ and $412 \pm 89 \mathrm{ka}(2 \sigma$, full external error, MSWD $=0.14$ and $\mathrm{P}=0.71$ ) were obtained for Isoletta ESR3 sands, associated to the "Acheulian level", and for Isoletta ESR4 sands respectively. The age of Isoletta ESR1 sands compared with ${ }^{40} \mathrm{Ar} /{ }^{39} \mathrm{Ar}$ results seems overestimated whatever the centre used. In addition, as the Ti-Li age is greatly higher than $\mathrm{Al}$ one, we the mean age value was not calculated and we cannot interpret the obtained ages as deposition ages. There is also a very clear overestimation by $\mathrm{Ti}-\mathrm{H}$, which leads us to suppose that the problem may also be related to an incorrect estimate of the annual dose rather than to a poor initial bleaching of the quartz grains. Indeed, this level is composed of very coarse elements (blocks, pebbles,...) whose sandy matrix constitutes the dated sample. The absence of an in situ gamma measurement means that coarse elements (the main part of the sediment in the level) were not taken into account when determining the annual dose. This could explain the results obtained for this level.

\subsection{Lademagne}


For Upper level sediment from Lademagne, the Ti-H ESR signal was not distinguishable from background noise and was therefore not measured.

The ages determined by ESR using Ti-Li $(398 \pm 51 \mathrm{ka})$ and $\mathrm{Al}(406 \pm 51 \mathrm{ka})$ centres are overall consistent (table 4). As for the main part of Isoletta's samples, the close $\mathrm{D}_{\mathrm{e}}$ obtained using the Ti-Li and $\mathrm{Al}$ centres allows us to give a weighted average age of $402 \pm 71 \mathrm{ka}(2 \sigma$, Full external error, MSWD $=0.012$ and $\mathrm{P}=0.91$ ) for these upper sands. This average age is in agreement with the ${ }^{40} \mathrm{Ar} /{ }^{39} \mathrm{Ar}$ age $(389 \pm 8 \mathrm{ka})$ obtained for the Lad Sup sediment.

\subsection{Notarchirico}

Only level $2-6$ is directly compared with the ${ }^{40} \mathrm{Ar} /{ }^{39} \mathrm{Ar}$ result. Nevertheless, as the whole fluvial sequence (level $\mathrm{J}$ to $\mathrm{B}$ ) has developed in the same climatic stage (that ${ }^{40} \mathrm{Ar} /{ }^{39} \mathrm{Ar}$ dates place during MIS16, Pereira et al., 2015) and as the error range of the ESR ages is relatively wide, the ages of levels $\mathrm{H} 1$ and $\mathrm{H} 1 \mathrm{c}$ can be compared with the ${ }^{40} \mathrm{Ar} /{ }^{39} \mathrm{Ar}$ results (Pereira et al., 2015) obtained for the closest layers (table 5).

Unfortunately, the Ti centres of Notarchirico 2-6 sample could not be measured (Ti signal was too weak to be possible to distinguish it between background noise, even with two scan and only $\mathrm{Al}$ age has been calculated. Despite this, the Al ESR age is totally in agreement with the ${ }^{40} \mathrm{Ar} /{ }^{39} \mathrm{Ar}$ obtained on the youngest volcanic event reworked into this level.

For samples from $\mathrm{H} 1$ and H1c levels, the three ESR centres have been measured. As for the Isoletta site, the ESR ages obtained using the Ti-Li and Al centres are consistent with each other and with the ${ }^{40} \mathrm{Ar} /{ }^{39} \mathrm{Ar}$ ages (table 4) of the neighboring levels, whereas the $\mathrm{Ti}-\mathrm{H}$ ages are significantly much younger. The close $\mathrm{D}_{\mathrm{e}}$ obtained using the $\mathrm{Al}$ and Ti-Li centres allows us to give a weighted average age. Ages of $743 \pm 67 \mathrm{ka}(2 \sigma$, Full external error, MSWD $=0.024$ and $\mathrm{P}=0.88)$ and $736 \pm 70 \mathrm{ka}(2 \sigma$, Full external error, MSWD $=0.013$ and $\mathrm{P}=0.91$ ) were obtained for Notarchirico $\mathrm{H} 1$ and Notarchirico H1c samples respectively. We can also notice that the Al and Ti-Li ESR ages obtained for the lower levels of the Notarchirico sequence are significantly older than the date determined for level 2-6, but considering the error range associated with ages, this is still consistent with it. Moreover, the results of the $\mathrm{H} 1$ levels are much older than the ${ }^{40} \mathrm{Ar} /{ }^{39} \mathrm{Ar}$ ages of the levels that cover them and it would be desirable in the future to constrain this chronology by ${ }^{40} \mathrm{Ar} /{ }^{39} \mathrm{Ar}$ dating of sanidines extracted from these lower layers.

\section{Conclusion}

A multi-centre ESR approach was used on quartz grains extracted from Middle Pleistocene fluvial deposits of central Italy that were all dated by the ${ }^{40} \mathrm{Ar} /{ }^{39} \mathrm{Ar}$ method. For most of the samples analyzed except one sample from the Isoletta site (ESR1), the ages determined both from Ti-Li and Al signals are in agreement with each other and consistent with the ${ }^{40} \mathrm{Ar} /{ }^{39} \mathrm{Ar}$ ages (Fig. 8). The use of the Ti-Li centre is therefore appropriate for this time range. Furthermore, the Al results clearly show the usefulness of this centre when the fluvial sediments sampled are made of fine sand carried by clear water river (without any fine particles in suspension). An evidence of this transport condition is showed by the absence of silt or clay in the sandy layers.

Our results strengthen the validity of ESR-MC method to accurately date sedimentary successions in fluvial context. The only discordant sample, Isoletta ESR1, was carried out from extremely coarse and poorly sorted sediments probably of colluvial origin, in which quartz grains have probably not been completely bleached.

For the considered Middle Pleistocene time range (i.e. 700-300 ka), the Ti-H ages are quite systematically underestimated (Fig. 8), perhaps due to a saturation of the Ti-H traps. Ti-H seems provide $D_{e}$ saturating around 300 Gy leading to a quite systematic underestimation of the ages by comparison with ${ }^{40} \mathrm{Ar} /{ }^{39} \mathrm{Ar}$, except for ESR1 sample (Isoletta), where low $\mathrm{D}_{\mathrm{a}}$ value leads to obtain an age Ti-H older than the ${ }^{40} \mathrm{Ar} /{ }^{39} \mathrm{Ar}$ age and ESR4 sample (Isoletta) where this value of about $300 \mathrm{~Gy}$ makes it possible to obtain an age close to the ${ }^{40} \mathrm{Ar} /{ }^{39} \mathrm{Ar}$ age.

It seems therefore preferable to avoid the use of Ti-H centres to date early Middle Pleistocene levels, especially if the Ti-Li and $\mathrm{Al} \mathrm{D}_{\mathrm{e}}$ are greater than $300 \mathrm{~Gy}$. It would be interesting in the future to conduct similar approach, combining ${ }^{40} \mathrm{Ar} /{ }^{39} \mathrm{Ar}$ and multi-centre ESR, on deposits containing both fluvial quartz and volcanic minerals, from late Middle Pleistocene to Upper Pleistocene (300-50 ka) as 
well as late Lower Pleistocene times (1.0-0.7 Ma) to further test and validate the MC approach over a longer period of time.

\section{Aknowledgements}

We would like to thank the Italian archaeologists and administrative service that are allowed the realization of this study. The present study was financially supported by the project «Acheulean and volcanism in Italy» conducted by M.-H. Moncel (CNRS) and J-.J. Bahain (MNHN) in ATM program $(\mathrm{MNHN})$ «Les dynamiques socio-écosystèmiques, entre perturbations et résiliences environnementales et culturelles», the PHC Galileo project no. 28237WA «l'Acheuléen en Italie méridionale: Chronologie, Paléoanthropologie, Cultures» led by J.-J. Bahain (MNHN) and C. Peretto (University of Ferrara) and the Leakey Foundation supporting the new excavations at Notarchirico led by M-H. Moncel.

The ESR and mobile gamma-ray spectrometers of the French National Museum of Natural History were bought with the financial support of the 'Sesame Île-de-France' program and the 'Région Centre' respectively.

\section{$\underline{\text { References }}$}

Arnold, L., Stokes, S., Bailey, R., Fattahi, M., Colls, A., Tucker, G. 2003 Optical dating of potassium feldspar using far-red (1>665 nm) IRSL emissions: a comparative study using fluvial sediments from the Loire River, France. Quaternary Science Reviews 22, 1093-1098.

Biddittu, I., 1974. Giacimento pleistocenico ad amigdale acheuleane nel territorio di Ceprano, Frosinone. Memoria dell'Istituto Italiano di Paleontologia Umana, 2, 61-67.

Biddittu, I., Canetri, E., Comerci, V., Germani, M., Picchi, G., 2012. Nuove ricerche nel giacimento del Paleolitico inferiore di Lademagne, S. Giovanni Incarico (Frosinone). In: Ghini, G., Mari, Z. (Eds.), Lazio e Sabina. Edizioni Quasar, 9, 437-443

Brennan, B. J., Lyons R.G., Phillips S.W., 1991. Attenuation of alpha particle track dose for spherical grains. Nuclear Tracks Radiation Measurement, 18, 249-253.

Brennan, B. J. 2003, Beta doses to spherical grains. Radiation Measurements 37, 299-303.

Despriée J., Voinchet P., Tissoux H., Bahain J-J., Falguères C., Courcimault G., Dépont J., Moncel MH., Robin S., Arzarello M., Sala R., Marquer L., Messager E., Puaud S., Abdessadok S., 2011. Lower and Middle Pleistocene human settlements recorded in fluvial deposits of the middle Loire River Basin, Centre Region, France. Quaternary Science Reviews, 30, 11-12, 1474-1485.

Duval, M., Grün, R., Falguères, C., Bahain, J.J., Dolo, J.M., 2009. ESR dating of Lower Pleistocene fossil teeth: Limits of the single saturating exponential (SSE) function for the equivalent dose determination. Radiation Measurements, 44, 477-482.

Duval, M. 2012. Dose response curve of the ESR signal of the Aluminum center in quartz grains extracted from sediment. Ancient TL 30,1-10

Duval, M., and Guilarte, V., 2015. ESR dosimetry of optically bleached quartz grains extracted from Plio-quaternary sediment: evaluating some key aspects of the ESR signal associated to the Ti-center. Radiation Measurement, 78, 28-41

Grün, R. 1994. A cautionary note: use of the "water content" and "depth for cosmic ray dose rate" in AGE and DATA programs'. Ancient TL, 12, 50-51.

Guérin, G., Mercier, N., Adamiec, G., 2011. Dose-rate conversion factors: update. Ancient TL, 29, 58 .

Laurent, M. Falguères C., Bahain, J.J., Yokoyama, Y., 1994. Géochronologie du système de terrasses fluviatiles quaternaires du bassin de la Somme par datation RPE sur quartz, déséquilibres des familles de l'uranium et magnétostratigraphie. C.R. Académie Sciences Paris, 318, 521-526 
Laurent, M., Falguères C., Bahain, J.J., Rousseau, L., Van Vliet-Lanoë B., 1998. ESR dating of quartz extracted from Quaternary and Neogene sediments: method, potential and actual limits. Quaternary Science Reviews, 17, 1057-1061.

Lefèvre, D., Raynal, J.P., Vernet, G., Kieffer, G., Piperno, M. 2010. Tephro-stratigraphy and the age of ancient Southern Italian Acheulean settlements: The sites of Loreto and Notarchirico (Venosa, Basilicata, Italy). Quaternary International ; 223-224, 360-368

Ludwig, K.R., 2003, User's Manual for Isoplot/Ex, Version 3.0, A geochronological toolkit for Microsoft Excel Berkeley Geochronology Center . Special Publication, v. 4, Berkeley Geochronology Center, 2455 Ridge Road, Berkeley, CA 94709, USA.

Moncel, M.H., Landais, A., Lebreton, V., Combourieu-Nebout, N., Nomade, S., Bazin, L., 2018. Linking environmental changes with human occupations between 900 and $400 \mathrm{ka}$ in Western Europe.Quaternary International ; 480, 78-94.

Mercier, N., Falguères, C., 2007. Field gamma dose-rate measurement with a NaI(Tl) detector: reevaluation of the "threshold" technique. Ancient TL, 25,1.

Miallier, D., Sanzelle, S., Falguères, C., Fain, J., Montret, M., Pilleyre, T., Soumana, S., Laurent, M., Gamus, G., De Goër, D., Hervé, A. 1994. Intercomparaison of Tl and ESR signals from heated quartz grains. Radiation measurements, 23, 1, 143-153.

Muttoni, G., Scardia, G., Kent, D. V., 2013. A critique of evidence for human occupation of Europe older than the Jaramillo subchron ( 1 Ma): Comment on 'The oldest human fossil in Europe from Orce (Spain)' by Toro-Moyano et al. (2013). Journal of Human Evolution 65, 746-749

Muttoni, G., Scardia, G., Kent, D. V.,2018. Early hominins in Europe: The Galerian migration hypothesis. Quaternary Science Reviews 180, 1-29

Niespolo, E.M., Rutte, D., Deino, A., Renne, P.R., 2017. Intercalibration and age of the Alder Creek sanidine 40Ar/39Ar standard. Quaternary Geochronology 39, 205-213.

Parés, J.M., Arnold, L., Duval, M., Demuro, M., Pérez-González, A.,Bermúdez de Castro, J.M., Carbonell, E., Arsuaga, J.L., 2013. Reassessing the age of Atapuerca-TD6 (Spain): new paleomagnetic results Journal of Archaeological Science 40, 4586-4595

Pereira A., Nomade S., Voinchet P., Bahain J.-J, Falguères C., Garon H., Lefèvre D., Raynal J.-R., Scao V., Piperno M., 2015. The earliest securely dated hominin fossil in Italy and evidence of Acheulian occupation during glacial MIS 16 at Notarchirico (Venosa, Basilicata, Italy) Journal Quaternary Science, 30, 7, 639-650.

Pereira, A., Nomade, S., Moncel, M.H., Voinchet, P., Bahain, J.J., Biddittu, I., Falgueres, C., Giaccio, B., Manzi, G., Parenti, F., Scardia, G., Scao, V., Sottili G., Vietti, A. 2018. Integrated geochronology of Acheulian sites from the southern Latium (central Italy): Insights on human-environment interaction and the technological innovations during the MIS 11-MIS 10 period Quaternary Science Reviews, 187, 112-129

Piperno, M., Mallegni, F., Yokoyama, Y., 1990. Découverte d'un fémur humain dans les niveaux acheuleens de Notarchirico (Venosa, Basilicata, Italie), C. R. Acad. Sc. Paris, 1097-1102

Piperno, M., Lefèvre., D, Raynal, J.P., Tagliacozzo, A. 1999. Conclusioni generali. In: Notarchirico. Un sito del Pleistocene medio-antico nel bacino di Venosa (Basilicata). Ed. Osanna, Venosa; 537-543.

Piperno, M., Tagliacozzo, A. 2001. The Elephant Butchery area at the Middle Pleistocene site of Notarchirico (Venosa, Basilicata, Italy). The World of Elephants- International congress, Rome.

Prescott, J.R., Hutton, J. T., 1994. Cosmic ray contributions to dose rates for Luminescence and ESR Dating: Large depths and long-term time. Radiation Measurements. 23, 497-500 
Renne, P.R., Mundil, R., Balco, G., Min, K., Ludwig, K.R., 2011. Joint determination of ${ }^{40} \mathrm{~K}$ decay constants and ${ }^{40} \mathrm{Ar} /{ }^{40} \mathrm{~K}$ for the Fish Canyon sanidine standard, and improved accuracy for ${ }^{40} \mathrm{Ar} /{ }^{39} \mathrm{Ar}$ geochronology. Response to the comment by W.H. Schwarz et al. on Geochimica Cosmochimica Acta 75, 5097-5100.

Sardella, R., Palombo, M.R, Petronio, C., Bedettia, C., Pavi, M. 2006. The early Middle Pleistocene large mammal faunas of Italy: An overview. Quaternary International, 149, 104-109

Steiger, R.H., Jäger, E. 1977. Subcommission on geochronology: convention on the use of decay constants in geo and cosmochronology. Earth and Planetary Science Letters 36: 359-362.

Tissoux, H., Falguères C., Voinchet P., Toyoda S., Bahain J.J., Despriée J. 2007. Potential use of Ticenter in ESR dating of Fluvial Sediment. Quaternary Geochronology, 2, 1-4, 367-372

Tissoux, H., Voinchet, P., Lacquement, F., Prognon, F., Moreno, D., Falguères, C., Bahain, J.-J., Toyoda S. 2012. Investigation on non-optically bleachable components of ESR aluminium signal in quartz. Radiation Measurements, 47, 9, 894-899

Tissoux, H., Voinchet, P., Lerouge, C., 2017. Contribution of cathodoluminescence to the characterization and selection of quartz for ESR dating. abstract of LED conference Capetown 2017.

Toyoda, S., Falguères C., 2003. The method to represent the ESR signal intensity of the aluminium hole center in quartz for the purpose of dating. Advances in ESR applications, 20, 7-10.

Toyoda, S., Voinchet, P., Falguères, C., Dolo, J.M. \& Laurent, M. 2000. Bleaching of ESR signal by the sunlight: a laboratory experiment for establishing the ESR dating of sediments. Applied Radiation and Isotopes, 52, 5, 1357-1362.

Toyoda, S., Tsukamoto, S., Hameau, S., Usui, H., Suzuki, T. 2006 Dating of Japanese Quaternary tephras by ESR and luminescence methods Quaternary Geochronology, 1, 320-326

Voinchet, P., Falguères, C., Laurent, M., Toyoda, S., Bahain, J.-J. \& Dolo, J.M. 2003. Artificial optical bleaching of the Aluminium center in quartz implications to ESR dating of sediments. Quaternary Science Reviews, 22, 1335-1338

Voinchet, P., Bahain, J.-J., Falguères, C., Laurent, M., Dolo, J.-M., Despriée, J., Gageonnet R., 2004. ESR dating of quartz extracted from Quaternary sediments: Application to fluvial terraces system of Northern France. Quaternaire, 15, 135-141.

Voinchet, P., Falguères, C., Tissoux, H., Bahain, J.J., Despriée J., Pirouelle F. 2007. ESR dating of fluvial quartz: estimate of the minimal distance transport required for getting a maximum optical bleaching. Quaternary Geochronology, 2, 1-4, 363-366.

Voinchet P., Despriée J., Tissoux H., Falguères C., Bahain J.-J., Gageonnet R., Dépont J., Dolo J.-M., 2010. ESR chronology of alluvial deposits and first human settlements of the Middle Loire Basin (Region Centre, France). Quaternary Geochronology, 5, 2-3, 381-384

Voinchet, P., Yin, G., Falguères, C., Liu, C., Han, F., Sun, X., Bahain, J.-J. 2013. ESR dose response of $\mathrm{Al}$ centre measured in quartz samples from the Yellow River (China): Implications for the dating of Upper Pleistocene sediment. Geochronometria 40, 4, 341-347

Voinchet, P., Toyoda, S., Falguères, C., Hernandez, M., Tissoux, H., Moreno, D., Bahain, J.-J. 2015. Evaluation of ESR residual dose in quartz modern samples, an investigation on environmental dependence. Quaternary Geochronology, 30, 506-512.

Woda, C.A. Wagner, G., 2007. Non-monotonic dose dependence of the Ge and Ti-centres in quartz. Radiation Measurements. 42. 1441-1452.

Yokoyama, Y., Falguères, C., Quaegebeur, J.P., 1985. ESR dating of quartz from Quaternary sediments: first attempt. Nuclear tracks 10, 921-928. 


\section{Figures Caption}

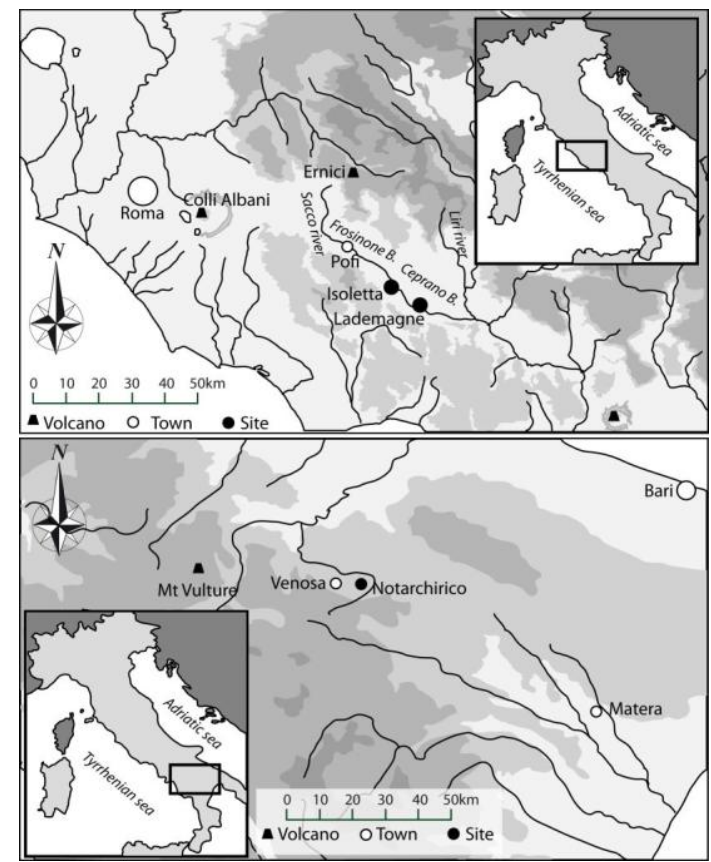

Fig.1. Location of Isoletta, Lademagne and Notarchirico sites (Italy)

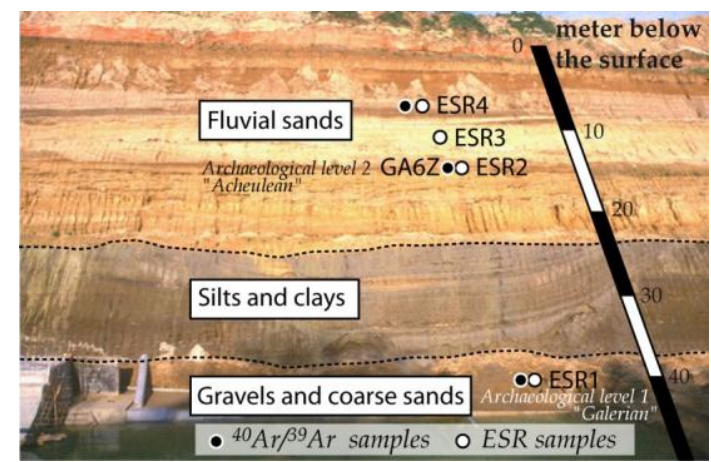

Fig.2. Cross section of Isoletta site and location of ESR and ${ }^{40} \mathrm{Ar} /{ }^{39} \mathrm{Ar}$ samples-Picture from Biddittu modified. 


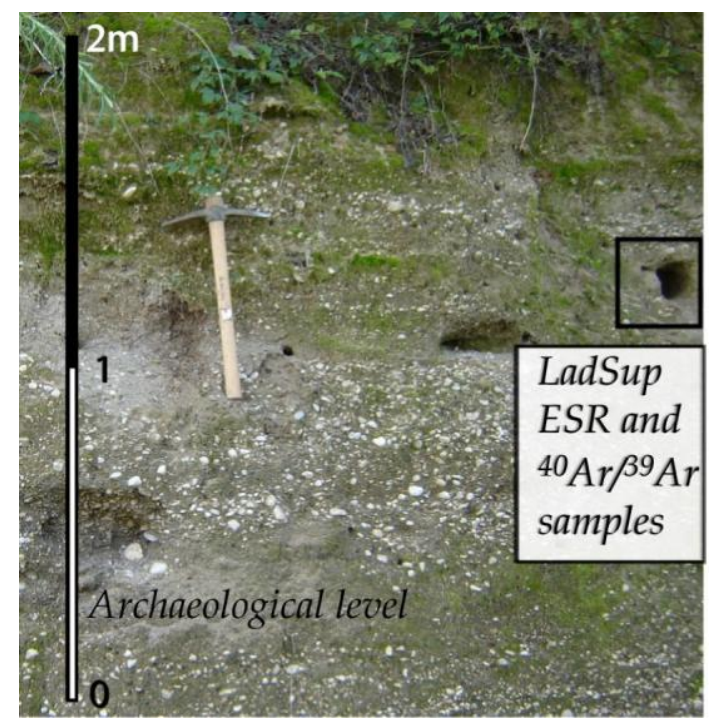

Fig.3: Cross section of Lademagne site and location of ${ }^{40} \mathrm{Ar} /{ }^{39} \mathrm{Ar}$ and ESR samples

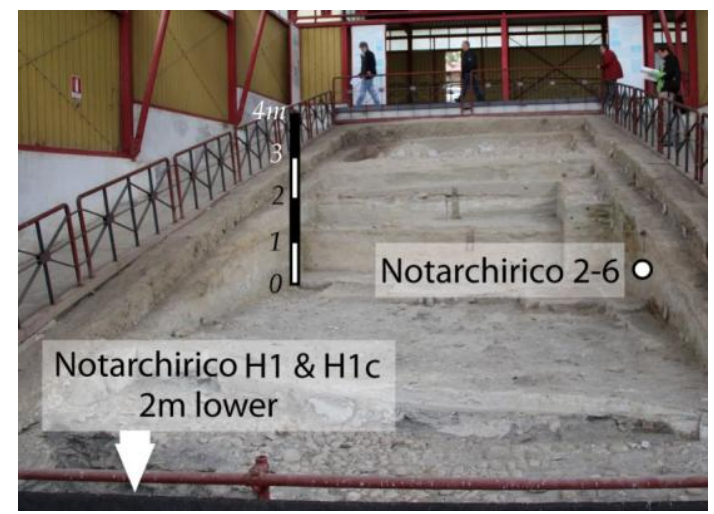

Fig.4: Notarchirico site and location of ESR samples 


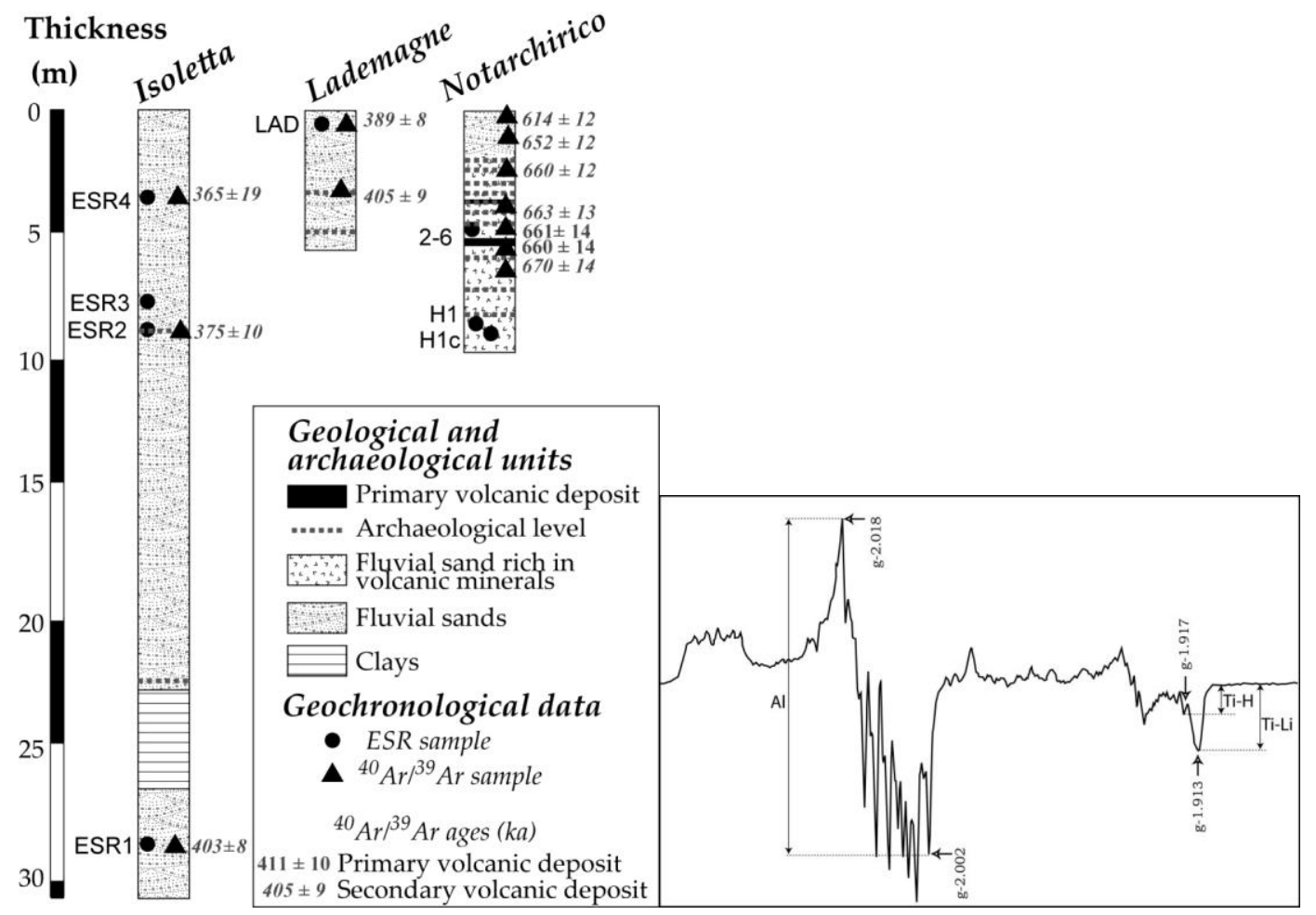

Fig.5: Stratigraphic sections of Isoletta, Lademagne and Notarchirico sites and ${ }^{40} \mathrm{Ar} /{ }^{39} \mathrm{Ar}$ results. ${ }^{40} \mathrm{Ar}{ }^{39} \mathrm{Ar}$ ages from primary and secondary volcanic deposits from Pereira et al, 2015 and 2018.

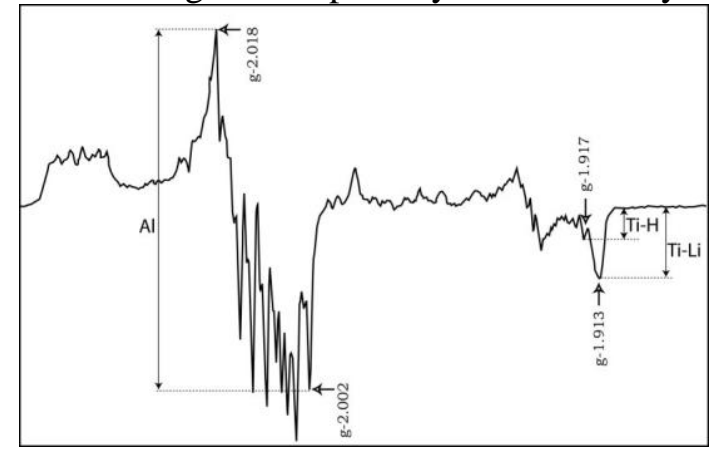

Fig 6: Isoletta ESR2 quartz grain ESR spectra (combination of two scans) with $\mathrm{Al}$, Ti-Li an Ti-H centers signals and indication of intensities measurements. 

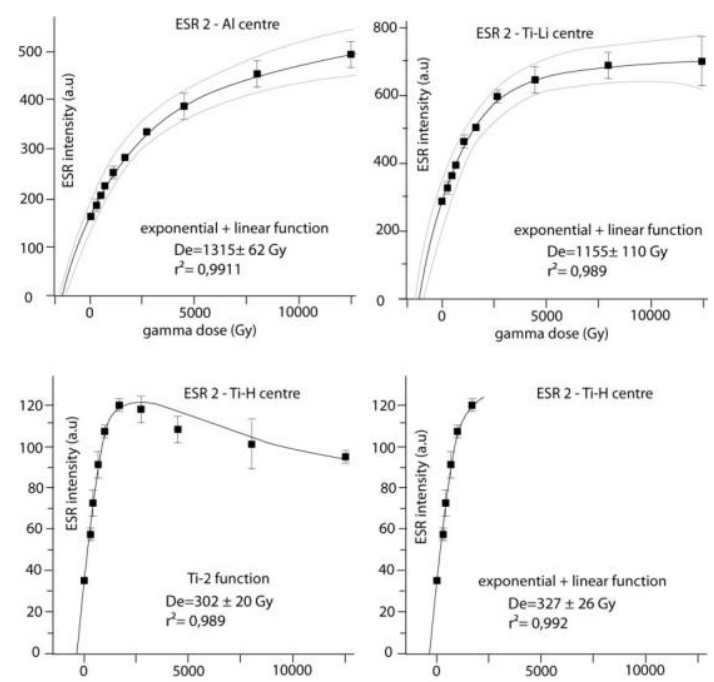

Fig.7: Growth curves obtained for Al, Ti-Li and Ti-H ESR centres. Comparison between De determined using Ti-2 and exponential+linear function for $\mathrm{Ti}-\mathrm{H}$ centre.

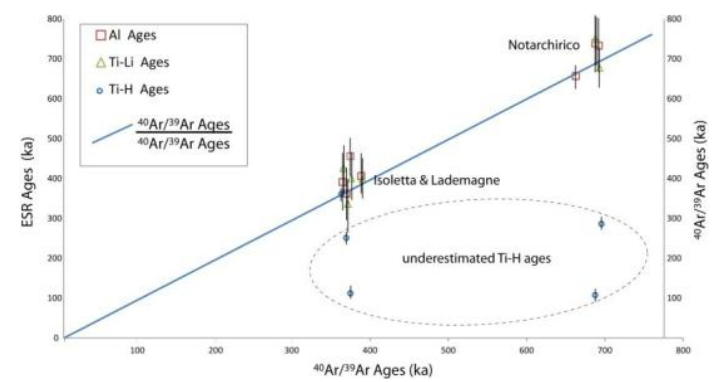

Fig.8: correlation between ESR ages obtained by different paramagnetic centres and ${ }^{40} \mathrm{Ar} /{ }^{39} \mathrm{Ar}$ ages solid line corresponds to the ${ }^{40} \mathrm{Ar}{ }^{39} \mathrm{Ar}$ ages compared with themselves. ESR age close to this line (or with error range crossing the line) are considered well estimated, result below this line are underestimated, ages above the line are overestimated. 


\begin{tabular}{|l|l|l|l|}
\hline & $\mathrm{U}(\mathrm{ppm})$ & $\mathrm{Th}(\mathrm{ppm})$ & $\mathrm{K}(\%)$ \\
\hline Isoletta ESR1 & $1.58 \pm 0.07$ & $0.31 \pm 0.07$ & $0.03 \pm 0.01$ \\
\hline Isoletta ESR2 & $1.62 \pm 0.14$ & $9.37 \pm 0.22$ & $2.39 \pm 0.03$ \\
\hline Isoletta ESR 3 & $1.79 \pm 0.09$ & $2.43 \pm 0.13$ & $0.44 \pm 0.01$ \\
\hline Isoletta ESR 4 & $1,40 \pm 0,06$ & $1.07 \pm 0.07$ & $0.23 \pm 0.01$ \\
\hline Lademagne Upper & $1.04 \pm 0.11$ & $2.91 \pm 0.06$ & $0.80 \pm 0.02$ \\
\hline Notarchirico 2-6 & $4.69 \pm 0.08$ & $4.87 \pm 0.04$ & $1.45 \pm 0.01$ \\
\hline Notarchirico H1 & $2.72 \pm 0.08$ & $4.48 \pm 0.04$ & $0.83 \pm 0.01$ \\
\hline Notarchirico H1-c & $3.22 \pm 0.09$ & $5.89 \pm 0.05$ & $1.07 \pm 0.01$ \\
\hline
\end{tabular}

Tab.1. Radionuclide contents, obtained with High Resolution Gamma Spectrometry, for analyzed sediments of Isoletta, Lademagne and Notarchirico Sites. Analytical uncertainties are given at $\pm 1 \sigma$ confidence level.

\begin{tabular}{|c|c|c|c|c|c|c|c|c|c|c|c|}
\hline & & $\begin{array}{l}\mathrm{D}_{\alpha} \\
\mu \mathrm{G} / \mathrm{a} / \\
\mathrm{a}\end{array}$ & $\begin{array}{l}D_{\beta} \\
\mu G y / a\end{array}$ & $\begin{array}{l}\mathrm{D}_{\gamma} \\
\mu \mathrm{Gy} / \mathrm{a}\end{array}$ & $\begin{array}{l}D_{\text {cos }} \\
\mu \mathrm{Gy} / \mathrm{a}\end{array}$ & $\begin{array}{l}D_{A} \\
\mu \mathrm{Gy} / \mathrm{a}\end{array}$ & $\begin{array}{l}\mathrm{W} \\
\%\end{array}$ & $\begin{array}{l}\text { B1 } \\
\%\end{array}$ & $\begin{array}{l}\mathrm{D}_{\mathrm{E}} \\
\text { (Gy) }\end{array}$ & $\mathrm{r}^{2}$ & $\begin{array}{l}\text { Age } \\
\text { (ka) }\end{array}$ \\
\hline \multicolumn{12}{|c|}{ Isoletta } \\
\hline \multirow{3}{*}{ ESR1 } & $\mathrm{Al}$ & \multirow{3}{*}{$19 \pm 1$} & \multirow{3}{*}{$190 \pm 11$} & \multirow{3}{*}{$168 \pm 10$} & \multirow{3}{*}{$24 \pm 1$} & \multirow{3}{*}{$401 \pm 15$} & \multirow{3}{*}{15} & 48 & $462 \pm 24$ & 0.992 & $1154 \pm 109$ \\
\hline & Ti-Li & & & & & & & \multirow{2}{*}{100} & $715 \pm 75$ & 0.986 & $1786 \pm 327$ \\
\hline & Ti-H & & & & & & & & $271 \pm 10$ & 0.997 & $677 \pm 47$ \\
\hline \multirow{3}{*}{ ESR2 } & $\mathrm{Al}$ & \multirow{3}{*}{$57 \pm 2$} & \multirow{3}{*}{$1786 \pm 36$} & \multirow{3}{*}{$1008 \pm 28$} & \multirow{3}{*}{$33 \pm 1$} & \multirow{3}{*}{$2884 \pm 15$} & \multirow{3}{*}{15} & 42 & $1315 \pm 62$ & 0.991 & $456 \pm 34$ \\
\hline & Ti-Li & & & & & & & \multirow[b]{2}{*}{100} & $1155 \pm 110$ & 0.989 & $401 \pm 59$ \\
\hline & Ti-H & & & & & & & & $327 \pm 36$ & 0.992 & $113 \pm 16$ \\
\hline \multirow{3}{*}{ ESR3 } & $\mathrm{Al}$ & \multirow{3}{*}{$30 \pm 2$} & \multirow{3}{*}{$497 \pm 20$} & \multirow{3}{*}{$354 \pm 16$} & \multirow{3}{*}{$53 \pm 3$} & \multirow{3}{*}{$934 \pm 26$} & \multirow{3}{*}{15} & 46 & $338 \pm 60$ & 0.981 & $362 \pm 64$ \\
\hline & Ti-Li & & & & & & & \multirow{2}{*}{100} & $314 \pm 73$ & 0.979 & $336 \pm 66$ \\
\hline & Ti-H & & & & & & & & $234 \pm 8$ & 0.997 & $250 \pm 15$ \\
\hline \multirow{3}{*}{ ESR4 } & $\mathrm{Al}$ & \multirow{3}{*}{$20 \pm 1$} & \multirow{3}{*}{$303 \pm 12$} & \multirow{3}{*}{$220 \pm 10$} & \multirow{3}{*}{$101 \pm 5$} & \multirow{3}{*}{$644 \pm 16$} & & 44 & $252 \pm 40$ & 0.984 & $391 \pm 72$ \\
\hline & Ti-Li & & & & & & 15 & 100 & $275 \pm 25$ & 0.989 & $426 \pm 59$ \\
\hline & Ti-H & & & & & & & 100 & $233 \pm 38$ & 0.987 & $361 \pm 90$ \\
\hline Laden & gne & & & & & & & & & & \\
\hline Lad & $\mathrm{Al}$ & & & & & & & 44 & $847 \pm 100$ & 0.981 & $406 \pm 51$ \\
\hline Sup & Ti-Li & $1 \pm 3$ & $980 \pm 35$ & $919 \pm 52$ & $111 \pm 6$ & $208 / \pm / 0$ & 5 & 100 & $831 \pm 70$ & 0.985 & $398 \pm 51$ \\
\hline Notarc & iirico & & & & & & & & & & \\
\hline $2-6$ & $\mathrm{Al}$ & $84 \pm 1$ & $1999 \pm 24$ & $1803 \pm 21$ & $166 \pm 8$ & $4052 \pm 32$ & 10 & 57 & $2658 \pm 122$ & 0.991 & $657 \pm 31$ \\
\hline & $\mathrm{Al}$ & & & & & & & 66 & $1942 \pm 60$ & 0.995 & $739 \pm 43$ \\
\hline H1 & Ti-Li & $\begin{array}{l}115 \pm \\
2\end{array}$ & $1203 \pm 20$ & $1215 \pm 18$ & $95 \pm 5$ & $2628 \pm 27$ & 17 & 100 & $1972 \pm 110$ & 0.995 & $750 \pm 57$ \\
\hline & Ti-H & & & & & & & 100 & $280 \pm 46$ & 0.984 & $107 \pm 33$ \\
\hline & $\mathrm{Al}$ & & & & & & & 69 & $2425 \pm 85$ & 0.993 & $732 \pm 49$ \\
\hline H1-c & Ti-Li & $2^{146 \pm}$ & $1521 \pm 23$ & $1551 \pm 22$ & $95 \pm 5$ & $3313 \pm 32$ & 17 & & $2453 \pm 100$ & 0.989 & $740 \pm 52$ \\
\hline & Ti-H & & & & & & & 100 & $952 \pm 65$ & 0.985 & $287 \pm 31$ \\
\hline
\end{tabular}

Tab. 2. ESR results obtained on quartz extracted from sediments. Analytical uncertainties and ages are given with $\pm 1 \sigma$. Water contents (W\%) were estimated by the difference in mass between the natural sample and the same sample dried for a week in an oven at $50^{\circ} \mathrm{C}(323.15 \mathrm{~K})$. Dose rates were determined using dose rate conversion factor updated by Guerin et al (2011). Alpha and beta attenuations estimated for the selected grain sizes from the tables of Brennan (2003); k-value of 0.15 (Yokoyama et al., 1985), cosmic dose rate calculated from the equations of Prescott \& Hutton (1994).

\begin{tabular}{|l|ll|ll|ll|ll|l|}
\hline & $\begin{array}{l}\text { Al } \\
\text { ages }\end{array}$ & ESR & $\begin{array}{l}\text { Ti-Li } \\
\text { ages }\end{array}$ & ESR & $\begin{array}{l}\text { Mean } \\
\text { ages }\end{array}$ & ESR & $\begin{array}{l}\text { Ti-H } \\
\text { ages }\end{array}$ & ESR & ${ }^{40} \mathrm{Ar} /{ }^{39}$ Ar ages \\
\hline
\end{tabular}




\begin{tabular}{|l|l|l|l|l|l|}
\hline ESR1 & $1154 \pm 109 \mathrm{ka}$ & $1786 \pm 327 \mathrm{ka}$ & Not calculated & $677 \pm 47 \mathrm{ka}$ & $403 \pm 8 \mathrm{ka}$ \\
\hline ESR2 & $456 \pm 34 \mathrm{ka}$ & $401 \pm 59 \mathrm{ka}$ & $442 \pm 58 \mathrm{ka}$ & $113 \pm 16 \mathrm{ka}$ & $375 \pm 10 \mathrm{ka}$ \\
\hline ESR3 & $362 \pm 64 \mathrm{ka}$ & $336 \pm 66 \mathrm{ka}$ & $349 \pm 90 \mathrm{ka}$ & $250 \pm 15 \mathrm{ka}$ & $365<$ expected $<375$ \\
\hline ESR4 & $391 \pm 72 \mathrm{ka}$ & $426 \pm 59 \mathrm{ka}$ & $412 \pm 89 \mathrm{ka}$ & $361 \pm 90 \mathrm{ka}$ & $365 \pm 19 \mathrm{ka}$ \\
\hline
\end{tabular}

Tab. 3. Isoletta Site, Comparison between ESR and ${ }^{40} \mathrm{Ar} /{ }^{39} \mathrm{Ar}$ ages. ${ }^{40} \mathrm{Ar} /{ }^{39} \mathrm{Ar}$ ages are already published in Perieira et al 2018. Ti-H ages are not used for mean ages calculation.

\begin{tabular}{|l|l|l|l|l|l|}
\hline & Al ESR age & Ti-Li ESR age & Mean ESR age & $\begin{array}{l}\text { Ti-H ESR } \\
\text { age }\end{array}$ & ${ }^{40} \mathrm{Ar}{ }^{39} \mathrm{Ar}$ age \\
\hline Lad Sup & $406 \pm 51 \mathrm{ka}$ & $398 \pm 51 \mathrm{ka}$ & $402 \pm 71 \mathrm{ka}$ & Uncalculable & $389 \pm 8 \mathrm{ka}$ \\
\hline
\end{tabular}

Tab. 4. Lademagne Site, Comparison between ESR and ${ }^{40} \mathrm{Ar} /{ }^{39} \mathrm{Ar}$ ages; ${ }^{40} \mathrm{Ar} /{ }^{39} \mathrm{Ar}$ ages are already published in Perieira et al 2018.

\begin{tabular}{|l|l|l|l|l|l|}
\hline & Al ESR ages & Ti-Li ESR ages & Mean ESR ages & TiH ESR ages & ${ }^{40} \mathrm{Ar} /{ }^{39} \mathrm{Ar}$ ages \\
\hline $\begin{array}{l}\text { Notarchirico } \\
2-6\end{array}$ & $657 \pm 31 \mathrm{ka}$ & not calculable & $657 \pm 31 \mathrm{ka}$ & not calculable & $663 \pm 13 \mathrm{ka}$ \\
\hline $\begin{array}{l}\text { Notarchirico } \\
\text { H1 }\end{array}$ & $739 \pm 43$ & $750 \pm 57$ & $743 \pm 67 \mathrm{ka}$ & $107 \pm 33 \mathrm{ka}$ & $>670 \pm 14 \mathrm{ka}$ \\
\hline $\begin{array}{l}\text { Notarchirico } \\
\text { H1c }\end{array}$ & $732 \pm 49$ & $740 \pm 52$ & $736 \pm 70 \mathrm{ka}$ & $287 \pm 31 \mathrm{ka}$ & $>670 \pm 14 \mathrm{ka}$ \\
\hline
\end{tabular}

Tab. 5 Notarchirico Site, Comparison between ESR and ${ }^{40} \mathrm{Ar} /{ }^{39} \mathrm{Ar}$ ages. ${ }^{40} \mathrm{Ar} /{ }^{39} \mathrm{Ar}$ ages are already published in Perieira et al 2015. Ti-H ages are not used for mean age calculation. 